\title{
Inclusion of Sunflower Meal, With or Without Enzyme Supplementation, in Broiler Diets
}

- Author(s)
Tavernari FC*
Albino LFT2
Morata RL'
Dutra Júnior WM3
Rostagno HS²
Viana MTS'
1 Ph.D. student in Monogastric Nutrition and
Production/UFV.
2 Head Professor of the Department of Animal
Science/UFV.
3 Assistant Professor of the Department of
Animal Science/UFRPE.

\section{Mail Address}

Fernando C. Tavernari

Federal University of Viçosa

Av. Peter Henry Rolfs, s/n

Cidade Universitária

36.570-000. Viçosa, MG, Brasil.

E-mail: fetavernari@yahoo.com.br

\section{Keywords}

Alternative feedstuffs, broiler production, enzyme complex.

\section{Acknowledgments}

The authors thank Programa de Cooperação Acadêmica (PROCAD/CAPES) for the M.Sc. grant, Bunge Foods for providing the sunflower meal, and Adisseo for providing the enzyme complex.

\section{ABSTRACT}

Two experiments were carried out to evaluate the effects of the dietary inclusion of different dietary sunflower meal (SFM) levels $(0 \%$ and $20 \%$, with or without the supplementation of an enzyme complex (EC) (cellulase, $\beta$-glucanase, xylanase, and phytase) on broiler performance, carcass and cuts yields, economics, and dietary AMEn values. A randomized block experimental design, with a $2 \times 2$ factorial arrangement of eight replicates of 20 birds each, was used to test performance. A completely randomized experimental design with a $2 \times 2$ factorial arrangement of eight replicates of four birds each was used to test metabolism. No interaction effects between SFM and EC were observed on performance. Although SFM significantly reduced feed intake in the starter phase and total period, weight gain was not different in these phases. Feed: gain ratio improved with the use of SFM in all phases, probably due to the dietary inclusion of oil, which may have improved digestibility. There was a significant increase in weight gain with the use of EC in the starter phase, which is possibly explained by the immature digestive system of birds at this age. There were no SFM or EC significant effects on carcass or cuts yields. There was no significant effect of the addition of EC on dietary AMEn values; however, EC significantly improved the apparent metabolizability coefficients of phosphorus and calcium.

\section{INTRODUCTION}

The low metabolizable energy of sunflower meal and its deficient utilization by non-ruminant animals are directly related to its high fiber content, resulting in worse live performance (Furlan et al., 2001).

Waldroup et al. (1970) concluded it is possible include up to $20 \%$ of sunflower meal broiler diets with no lysine supplementation, which was later confirmed by Valdivie et al. (1982) and Zatari \& Sell (1990). However, Furlan et al. (2001) asserted that up to $15 \%$ of sunflower meal can be included in broiler feeds with no effect on performance, provided lysine is supplemented; however, lower feed cost per kilogram of body weight gain ratio, better economic efficiency index, and feed cost were observed with $0 \%$ of inclusion of sunflower meal. Pinheiro et al. (2002) found better economic performance when broilers were fed $0 \%$ sunflower meal from three to 35 days of age, and $4 \%$ sunflower meal from 36 to 42 days of age.

Monogastric animals do not have endogenous capacity to digest fiber, and therefore, the use of exogenous enzymes is important as they hydrolyze non-starch polysaccharides that can potentially be used by the animals, improving, for instance, energy use.

Senkoylu \& Dale (1999), in a review on sunflower meal, proposed that the addition of exogenous enzymes is required when this raw 
Tavernari FC, Albino LFT, Morata RL, Dutra Júnior WM, Rostagno HS, Viana MTS
Inclusion of Sunflower Meal, With or Without Enzyme Supplementation, in Broiler Diets material is used due to its high non-starch polysaccharide content.

Oliveira et al. (2007) evaluated two sunflower meal inclusion levels (0 and 15\%), with or without an enzyme complex (cellulase, protease, and amylase) in the diet of 21 to 42-day-old broilers, and did not find any significant interactions between sunflower meal and the enzyme complex. Those authors concluded that the dietary inclusion of $15 \%$ sunflower meal improves live performance, but does not affect carcass yield.

The objective of the present experiments was to evaluate live performance, carcass yield and cuts, economic feasibility, and metabolizable energy content of diets containing $0 \%$ or $20 \%$ sunflower meal, and supplemented or not with enzymes.

\section{MATERIAL AND METHODS}

Two experiments were carried out at the Poultry Sector of the Department of Animal Science of the Federal University of Viçosa, MG, Brazil.

The first experiment evaluated the performance of 640 one- to 42-day-old male Cobb broilers. Birds were housed in a masonry broiler house, equipped with screens, and with a clay-tiled roof, divided in $1.0 \times 1.5$ $\mathrm{m}$ pens, provided with wood-shavings litter, a nipple drinker, and a tube feeder.

The average environmental temperatures recorded during the experiment were: $25.5^{\circ} \mathrm{C}\left(20.0\right.$ and $31.0^{\circ} \mathrm{C}$ of minimum and maximum temperatures, respectively) from 1 to 21 days, and $24.5^{\circ} \mathrm{C}\left(19.0\right.$ and $30.0^{\circ} \mathrm{C}$ of minimum and maximum temperatures, respectively) from 21 to 42 days.

A randomized block experimental design with four treatments in a $2 \times 2$ factorial arrangement (two sunflower meal inclusion levels: $0 \%$ and 20\%; and supplementation or not of an enzyme complex), with eight replicates of 20 birds each.

Diets were formulated according to Rostagno et al. (2005) (Tables 1 and 2). Sunflower meal contained 89.95\% DM, $28.09 \%$ CP, and $22.37 \%$ CF. The used enzyme complex was Rovábio Max (cellulase, $\beta$ glucanase, xylanase, and phytase) at $100 \mathrm{~g} / \mathrm{MT}$ of feed.

The experimental diets contained equal levels of calories, of protein, and of the main digestible amino acids. No nutritional value was considered for the enzyme complex.

Birds and diets were weighed at beginning and in the end of each experimental phase (01 to 21 days, and 22 to 42 days) in order to calculate the following parameters: weight gain, feed intake, and feed: gain ratio at 21 and 42 days of age, and livability and production index at 42 days. Carcass traits, such as carcass yield, breast, thigh and drumstick, and abdominal fat yields, were also assessed.

The economic feasibility of the dietary inclusion of sunflower meal was assessed first by calculating feed cost per kilogram of body weight gain (Yi), as proposed by Bellaver et al. (1985).

\section{$Y i=(P i * Q i) / W i$,}

where $\mathrm{Yi}$ is the feed cost per kilogram of body weight gain in the nth treatment; Pi, price per kilogram of feed used in the nth treatment; Qi, feed intake amount in the nth treatment; and $\mathrm{Wi}$, weight gain of the nth treatment. Then, the Economic Efficiency Index (EEI) and the Cost Index (IC) proposed by Fialho et al. (1992) were calculated.

\section{$\mathrm{EEI}=(\mathrm{MCe} / \mathrm{CTei}) * 100$ and $\mathrm{Cl}=(\mathrm{CTei} / \mathrm{MCe}) * 100$,}

where MCe is the lowest feed cost per kilogram of weight gain observed among treatments; and CTei, cost of the i treatment.

\begin{tabular}{|c|c|c|}
\hline \multirow[t]{2}{*}{ Ingredients (\%) } & \multicolumn{2}{|c|}{ Sunflower meal inclusion levels } \\
\hline & $0 \%$ & $20 \%$ \\
\hline Corn & 56.97 & 43.89 \\
\hline Soybean meal & 36.74 & 26.77 \\
\hline Sunflower meal & 0.00 & 20.00 \\
\hline Soybean oil & 2.30 & 5.30 \\
\hline Dicalcium phosphate & 1.85 & 1.71 \\
\hline Limestone & 0.91 & 0.92 \\
\hline Salt & 0.50 & 0.49 \\
\hline DL-Methionine $99 \%$ & 0.24 & 0.21 \\
\hline L-lysine $\mathrm{HCl}$ 99\% & 0.15 & 0.33 \\
\hline L-Threonine 98\% & 0.03 & 0.06 \\
\hline Vitamin premix ${ }^{1}$ & 0.10 & 0.10 \\
\hline Mineral premix ${ }^{2}$ & 0.05 & 0.05 \\
\hline Choline chloride $60 \%$ & 0.10 & 0.10 \\
\hline Anticocidial (salinomycin 12\%) & 0.06 & 0.06 \\
\hline Antioxidant $^{3}$ & 0.01 & 0.01 \\
\hline \multicolumn{3}{|l|}{ Calculated composition } \\
\hline Metabolizable energy, kcal/kg & 2,975 & 2,975 \\
\hline Crude protein, \% & 21.50 & 21,50 \\
\hline Crude protein, $\%^{4}$ & 21.19 & 21.31 \\
\hline Crude fiber, \% & 2.97 & 6.68 \\
\hline Calcium, \% & 0.91 & 0.91 \\
\hline Total phosphorus, \% & 0.67 & 0.73 \\
\hline Available phosphorus, \% & 0.45 & 0.45 \\
\hline Available lysine, \% & 1.17 & 1.17 \\
\hline Available methionine + cystine, \% & 0.83 & 0.83 \\
\hline Available methionine, $\%$ & 0.54 & 0.54 \\
\hline \multicolumn{3}{|c|}{ 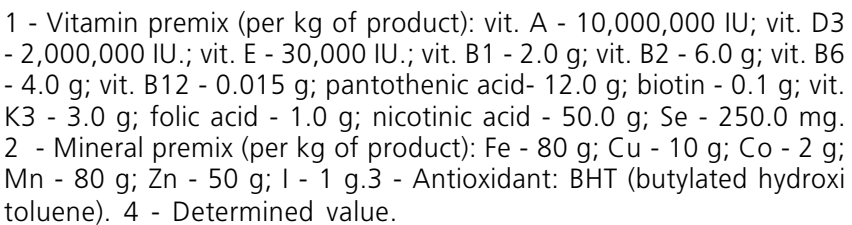 } \\
\hline
\end{tabular}


Tavernari FC, Albino LFT, Morata RL, Dutra Júnior WM, Rostagno HS, Viana MTS
Inclusion of Sunflower Meal, With or Without Enzyme Supplementation, in Broiler Diets

\begin{tabular}{|c|c|c|}
\hline \multirow[t]{2}{*}{ Ingredients (\%) } & \multicolumn{2}{|c|}{ Sunflower meal inclusion levels } \\
\hline & $0 \%$ & $20 \%$ \\
\hline Corn & 62.56 & 47.23 \\
\hline Soybean meal & 30.57 & 21.95 \\
\hline Sunflower meal & 0.00 & 20.00 \\
\hline Soybean oil & 3.15 & 7.17 \\
\hline Dicalcium phosphate & 1.65 & 1.49 \\
\hline Limestone & 0.85 & 0.85 \\
\hline Salt & 0.47 & 0.46 \\
\hline DL-Methionine $99 \%$ & 0.21 & 0.15 \\
\hline L-lysine HCl 99\% & 0.18 & 0.32 \\
\hline L-Threonine $98 \%$ & 0.04 & 0.06 \\
\hline$V^{\text {Vitamin }}$ premix ${ }^{1}$ & 0.10 & 0.10 \\
\hline Mineral premix ${ }^{2}$ & 0.05 & 0.05 \\
\hline Choline chloride 60\% & 0.10 & 0.10 \\
\hline Anticocidial (salinomycin 12\%) & 0.06 & 0.06 \\
\hline Antioxidant $^{3}$ & 0.01 & 0.01 \\
\hline \multicolumn{3}{|l|}{ Calculated composition } \\
\hline Metabolizable energy, $\mathrm{kcal} / \mathrm{kg}$ & 3,100 & 3,100 \\
\hline Crude protein, \% & 19.15 & 19.15 \\
\hline Crude protein, $\%^{4}$ & 19.10 & 19.73 \\
\hline Crude fiber, \% & 2.74 & 6.94 \\
\hline Calcium, \% & 0.82 & 0.82 \\
\hline Total phosphorus, \% & 0.62 & 0.68 \\
\hline Available phosphorus, \% & 0.41 & 0.41 \\
\hline Available lysine, \% & 1.05 & 1.05 \\
\hline Available methionine + cystine, \% & 0.76 & 0.76 \\
\hline Available methionine, \% & 0.49 & 0.47 \\
\hline \multicolumn{3}{|c|}{ 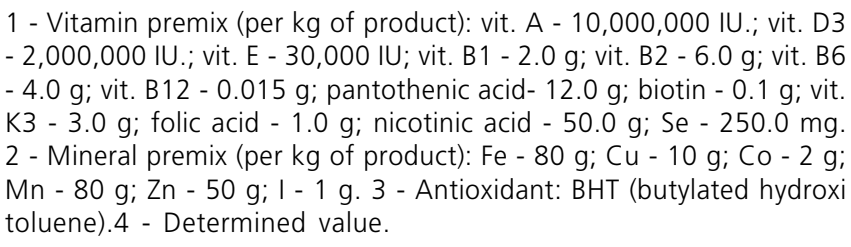 } \\
\hline
\end{tabular}

In the second experiment, a metabolism trial, 160 Cobb broilers, from 15 to 24 days of age and $467 \mathrm{~g}$ average body weight, were used to estimate the dry matter apparent digestibility (DMAD), apparent metabolizable energy corrected for nitrogen (AMEn), and gross energy metabolizability coefficient (GEMC) of the starter feeds fed in the performance experiment described above, using the total excreta collection method. A completely randomized experimental design with four treatments in a $2 \times 2$ factorial arrangement (two sunflower meal inclusion levels: $0 \%$ and $20 \%$; and the addition or not of an enzyme complex), with eight replicates of five birds each, was applied.

The average temperatures recorded during the experiment were: $23.0^{\circ} \mathrm{C}\left(17.0\right.$ and $29.0^{\circ} \mathrm{C}$ minimum and maximum temperatures, respectively).

Chicks were reared in a masonry broiler house from 1 to 14 days of age, and then transferred to metabolic cages. The total experimental period was nine days, with four days for bird adaptation to the experimental diets and cages, and the remaining five days for excreta collection, which was carried out twice daily, at 12-h intervals. In order to prevent sample contamination and loss, trays lined with plastic sheets were placed under each metabolic cage.

Collected excreta samples were placed in plastic bags, duly identified, weighed, and stored in a freezer. At the end of the collection period, excreta were homogenized, and aliquots were taken and placed in a forced-circulation oven at $55^{\circ} \mathrm{C}$ for pre-drying. Laboratory analyses were subsequently carried out, according to the techniques described by Silva \& Queiroz (2002).

At the end of the experiment, feed intake per experimental unit during the five days of excreta collection was determined. Once the results of laboratory analyses of the feed ingredients, reference feed, test feeds, and excreta were obtained, AME and AMEn were calculated according to the models proposed by Matterson et al. (1965). Calcium and phosphorus apparent metabolizability coefficients were calculated using the following formula:

$$
A M C=((M t i-M t e) / M t i) * 100,
$$

where AMC is the apparent metabolizability coefficient of the evaluated mineral, Mti is the total intake of the evaluated mineral, and Mte is the total excretion of the evaluated mineral.

Data were submitted to analysis of variance. Data normality and homogeneity test did not indicate any need of data transformation. Means were compared by the SNK test, at $5 \%$ probability, with aid of SAEG (System of Statistics and Genetic Analysis) statistical software (UFV, 2000).

\section{RESULTS AND DISCUSSION}

The performance results obtained in the starter (1 21 days) and grower (22 - 42 days) phases, as well as for the total experimental period ( 1 - 42 days) are presented in Tables 3, 4, and 5.

No significant interaction between sunflower meal and enzyme complex on feed intake, weight gain and feed:gain ratio was observed in none of the periods.

During the starter phase and total experiment period, feed intake was significantly reduced with the use of sunflower meal, which may be explained by the high crude fiber content of this diet and the high oil level of the experimental feeds. Furlan et al. (2001) found no significant difference in feed intake for the starter and grower phases or total experimental period with the dietary addition of sunflower meal. 


\begin{tabular}{|c|c|c|c|c|c|}
\hline \multicolumn{4}{|c|}{$\begin{array}{l}\text { Table } 3 \text { - Effect of sunflower meal inclusion levels (SFM), with or } \\
\text { with no addition of enzyme complex (EC) on feed intake (FI), } \\
\text { weight gain, (WG), and feed: gain ratio (F:G) of broiler during } \\
\text { the starter phase (1-21 days). }\end{array}$} & & \\
\hline & & \multicolumn{2}{|c|}{ Sunflower meal } & $\begin{array}{c}\text { EC } \\
\text { average }\end{array}$ & $\begin{array}{l}\text { CV } \\
(\%)\end{array}$ \\
\hline \multirow{3}{*}{$\mathrm{FI}$ (g/bird) } & With EC & 1.185 & 1141 & 1162 & \multirow{3}{*}{2.832} \\
\hline & With no EC & 1.211 & 1.159 & 1.185 & \\
\hline & SFM average & $1.198 a$ & $1.150 \mathrm{~b}$ & & \\
\hline \multirow[t]{3}{*}{ WG (g/bird) } & With EC & 0.852 & 0.850 & $0.851 \mathrm{~B}$ & \multirow[t]{3}{*}{2.627} \\
\hline & With no EC & 0.874 & 0.865 & $0.870 \mathrm{~A}$ & \\
\hline & SFM average & 0.863 & 0.857 & & \\
\hline \multirow[t]{3}{*}{$F: G(g / g)$} & With EC & 1.392 & 1.344 & 1.368 & \multirow[t]{3}{*}{1.675} \\
\hline & With no EC & 1.385 & 1.340 & 1.363 & \\
\hline & SFM average & $1.389 b$ & $1.342 a$ & & \\
\hline
\end{tabular}

$a, b$ - Means followed by different letters in the same row are different $(P<0,05)$ by the SNK test. $A, B$ - Means followed by different letters in the same column are different $(P<0,05)$ by the SNK test.

Table 4 - Effect of sunflower meal inclusion levels (SFM), with or with no addition of enzyme complex (EC), on feed intake (FI), weight gain, (WG), and feed: gain ratio $(F: G)$ of broiler during the grower phase (22-42 days).

\begin{tabular}{|c|c|c|c|c|c|}
\hline & \multirow[b]{2}{*}{$0 \%$} & \multicolumn{2}{|c|}{ Sunflower meal } & \multirow{2}{*}{$\begin{array}{c}\text { EC } \\
(\%)\end{array}$} & \multirow[t]{2}{*}{ CV } \\
\hline & & $20 \%$ & average & & \\
\hline \multirow{3}{*}{ Fl (g/bird) } & With EC & 3.192 & 3.174 & 3.183 & \multirow{3}{*}{2.595} \\
\hline & With no EC & 3.242 & 3.189 & 3.216 & \\
\hline & SFM average & 3.217 & 3.181 & & \\
\hline \multirow[t]{3}{*}{ WG (g/bird) } & With EC & 1.799 & 1.825 & 1.812 & \multirow[t]{3}{*}{3.302} \\
\hline & With no EC & 1.811 & 1.846 & 1.828 & \\
\hline & SFM average & 1.805 & 1.836 & & \\
\hline \multirow[t]{3}{*}{$F: G(g / g)$} & With EC & 1.775 & 1.740 & 1.757 & \multirow[t]{3}{*}{2.582} \\
\hline & With no EC & 1.791 & 1.728 & 1.760 & \\
\hline & SFM average & $1.783 b$ & $1.734 a$ & & \\
\hline
\end{tabular}

$a, b$ - Means followed by different letters in the same row are different $(\mathrm{P}<0.05)$ by the SNK test.

\begin{tabular}{|c|c|c|c|c|c|}
\hline & & Sunflo & er meal & EC & CV \\
\hline & $0 \%$ & $20 \%$ & $\overline{\text { average }}$ & $(\%)$ & \\
\hline \multirow[t]{3}{*}{$\mathrm{FI}$ (g/bird) } & With EC & 4,377 & 4,315 & 4,346 & 2.396 \\
\hline & With no EC & 4,453 & 4,348 & 4,401 & \\
\hline & SFM average & $4,415 a$ & $4,332 b$ & & \\
\hline \multirow[t]{3}{*}{ WG (g/bird) } & With EC & 2,651 & 2,675 & 2,663 & 2.471 \\
\hline & With no EC & 2,684 & 2,711 & 2,698 & \\
\hline & SFM average & 2,668 & 2,693 & & \\
\hline \multirow[t]{3}{*}{$F: G(g / g)$} & With EC & 1.651 & 1.613 & 1.632 & 1.846 \\
\hline & With no EC & 1.659 & 1.604 & 1.632 & \\
\hline & SFM average & $1.655 a$ & $1.609 b$ & & \\
\hline
\end{tabular}

$a, b$ - Means followed by different letters in the same row are different $(P<0,05)$ by the SNK test.

Although sunflower meal significantly reduced feed intake in the starter phase and the total experimental period, no effect was observed on weight gain, allowing us to infer that the high oil content improved diet digestibility.

Oliveira et al. (2007), testing 0 and $15 \%$ sunflower meal inclusion levels, with or with no enzyme supplementation, in grower broilers, did not find any significant effect of sunflower meal on feed intake; however, there was significant reduction in weight gain. In present study, no significant effect of sunflower meal on feed intake and weight gain during the grower stage was observed.

The enzyme complex had a significant effect on weight gain only during the starter phase possibly due to the immature digestive system of broilers at this age. It is known that after hatching, the broiler digestive system is anatomically complete, but its functional digestion and absorption capacities are still immature, with low secretion of pancreatic enzymes, which will only increase as feed intake and bird age increase (Maiorka et al., 2002).

Sunflower meal promoted significant improvement in feed:gain ratio during the starter and the grower phases, as well as during total experimental period. This is probably due to an interaction between nutrients, as oil inclusion level increased with sunflower meal dietary level in order to supply the birds' energy requirements, possibly improving diet digestibility.

The effects of sunflower meal dietary inclusion, with or with no enzyme supplementation on carcass yield, abdominal fat, thigh and drumstick, breast, and breast fillet yields are shown in Table 6 .

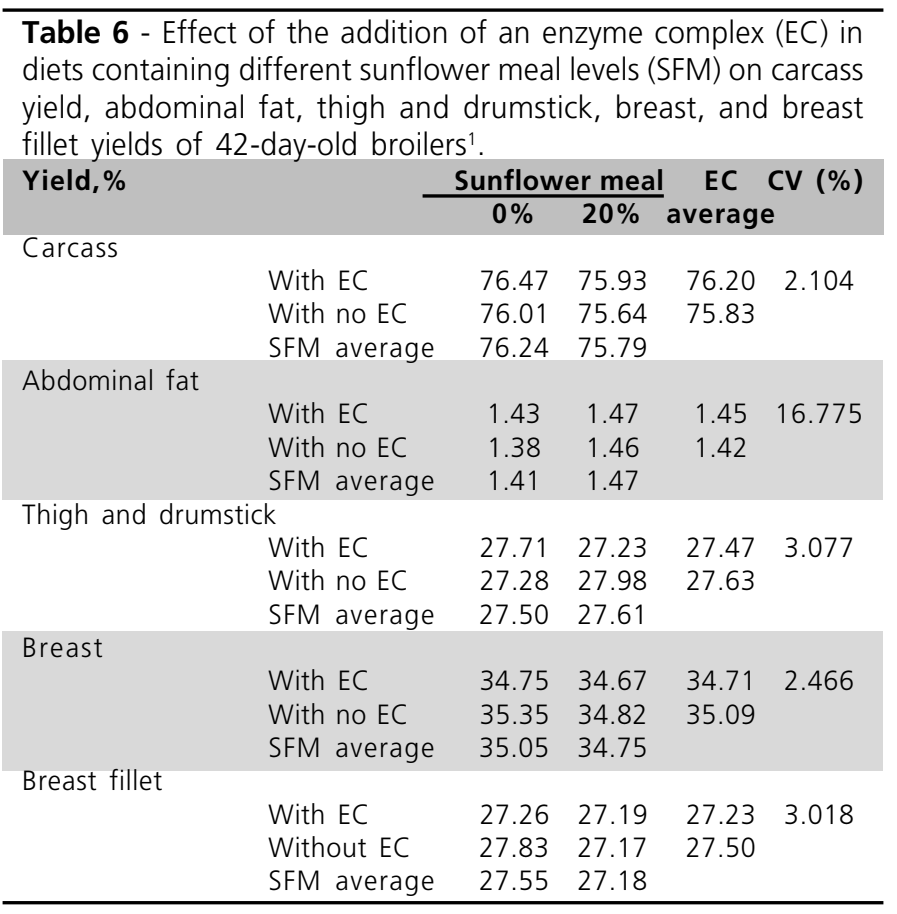

$1-(P>0.05)$

There was no interaction between sunflower meal and the enzyme complex, and no significant effect of 
sunflower meal or the enzyme complex on the evaluated parameters. Oliveira et al. (2003), evaluating 0,15 , and $30 \%$ sunflower meal levels in broiler diets, also did not observe any significant effect on carcass and cuts yields.

Dry matter apparent digestibility coefficient (DMADC), gross energy apparent metabolizability coefficient (GEAMC), and apparent metabolizable energy corrected for nitrogen (AMEn) values are shown in Table 7. No significant interaction between sunflower meal and the enzyme complex were detected for DMADC, GEAMC, or AMEn.

The dietary inclusion of sunflower meal increased AMEn, which may explain the improvement in feed:gain ratio of broilers during the starter phase.

\begin{tabular}{|c|c|c|c|c|c|}
\hline \multicolumn{6}{|c|}{$\begin{array}{l}\text { Table } 7 \text { - Effect of the addition of an enzyme complex (EC) in } \\
\text { diets containing different sunflower meal levels (SFM) on Dry } \\
\text { matter apparent digestibility coefficient of (DMADC) and gross } \\
\text { energy apparent metabolizability coefficient (GEAMC), expressed } \\
\text { as percentage (\%), and apparent metabolizable energy corrected } \\
\text { for nitrogen (AMEn) value expressed in kcal / kg (on as-fed basis). }\end{array}$} \\
\hline \multicolumn{4}{|c|}{ Sunflower meal } & \multirow{2}{*}{$\begin{array}{c}\text { EC } \\
\text { average }\end{array}$} & \multirow{2}{*}{$\begin{array}{l}\text { CV } \\
(\%)\end{array}$} \\
\hline & & $0 \%$ & $20 \%$ & & \\
\hline \multirow[t]{3}{*}{ DMADC } & With EC & 73.34 & 67.49 & 70.42 & 1.572 \\
\hline & & & & 71.09 & \\
\hline & SFM a & 73.6 & $67.8 . r-x-1$ & & \\
\hline \multirow[t]{3}{*}{ GEAMC } & With EC & 72.91 & & 70.70 & 1.358 \\
\hline & With $n$ & 73.25 & 68.77 & 71.01 & \\
\hline & SFM average & $73.08 \mathrm{~A}$ & 68.6 & & \\
\hline \multirow[t]{3}{*}{ AMEn } & With EC & 2,979 & 3,053 & 3,016 & 1.370 \\
\hline & & & & 3,029 & \\
\hline & SFM average & $2,986 \mathrm{~B}$ & $3,059 \mathrm{~A}$ & & \\
\hline
\end{tabular}

$A, B$ - Means followed by different letters in the same row are different $(P<0.05)$ by the SNK test.

Although the enzyme complex improved weight gain in the starter phase, no significant effect was observed on AMEn.

Phosphorus (PAMC) and calcium (CaAMC) apparent metabolizability coefficients are presented in Table 8 . There was a significant effect of the interaction between sunflower meal and the enzyme complex on PAMC and CaAMC

The diets with no inclusion of sunflower meal did not improve PAMC or CaAMC when the enzyme complex was added to the diet. However, the inclusion of $20 \%$ of sunflower meal in the diet reduced PAMC and CaAMC. According to Torin (1991), the reduction in mineral availability can be largely attributed to the presence of fiber, and in fact, may be as important as the presence of phytic acid. However, when the enzyme complex, which in addition to fiber-degrading enzymes also contains phytase, was added, phosphorus and calcium retention increased in broilers fed the diet containing 20\% sunflower meal.

\begin{tabular}{|c|c|c|c|c|}
\hline Treatment & $\begin{array}{c}\text { PAMC } \\
\text { With no EC }\end{array}$ & \multicolumn{3}{|c|}{ CaAMC } \\
\hline $0 \%$ SFM & 56.78Aa & $57.84 \mathrm{Aa}$ & $58.23 \mathrm{Aa}$ & 58.27Aa \\
\hline $20 \%$ SFM & $47.29 \mathrm{Bb}$ & $52.43 \mathrm{Ba}$ & $51.94 \mathrm{Bb}$ & $56.37 \mathrm{Ba}$ \\
\hline CV (\%) & 2.940 & & 2.923 & \\
\hline
\end{tabular}

A, B - Means followed by different letters in the same column are different $(P<0.05)$ by the SNK test. $a$, $b$ Means followed by different letters in the same row are different $(P<0.05)$ by the SNK test.

Table 9 shows feed cost per kilogram of body weight gain, economic efficiency index (EEI), and cost index (IC).

The results show that the lowest feed cost per kilogram of body weight gain and the highest economic efficiency and cost rates were obtained when the broilers received feeds containing 0\% sunflower meal, which is consistent with the results of Furlan et al. (2001).

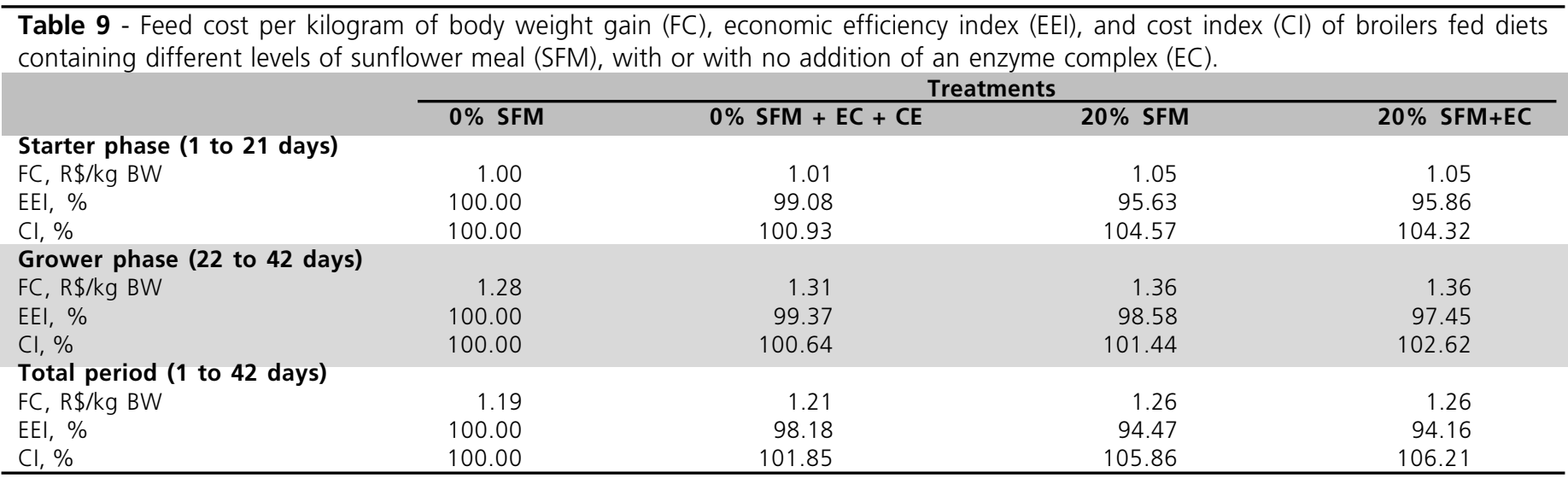




\section{CONCLUSIONS}

A level of $20 \%$ sunflower can be included in broiler feeds with no harmful effects on performance, provided oil and lysine are supplemented. However, it is not economically feasible, although this feasibility may vary with sunflower meal, oil, and synthetic lysine prices, if used. The addition of the enzyme complex does not change AMEn values; however, it improves phosphorus and calcium retention in diets containing sunflower meal.

\section{REFERENCES}

Bellaver C, Fialho ET, Protas JFS, Gomes PC. Radícula de malte na alimentação de suínos em crescimento e terminação. Pesquisa Agropecuária Brasileira 1985; 20(8):969-974.

Fialho ET, Barbosa O, Ferreira AS, Gomes PC, Girotto AF. Utilização da cevada suplementada com óleo de soja para suínos em crescimento e terminação. Pesquisa Agropecuária Brasileira 1992; 27(10):1467-1475.

Furlan AC, Mantovani C, Murakami AE, Moreira I, Scapinello C, Martins EM. Utilização do farelo de girassol na alimentação de frangos de corte. Revista Brasileira de Zootecnia 2001; 30(1):158164.

Maiorka A, Macari M, Furlan RL, Gonzales E. Fisiologia aviária aplicada a frangos de corte. Jaboticabal: FUNEP-UNESP; 2002. p. 113-124.

Matterson LD, Potter LM, Stutz MW, Singsen EP. The metabolizable energy of feed ingredients for chickens. Storrs: The University of Connecticut, Agricultural Experiment Station;1965. 11p. (Research Report, 7).

Oliveira MC, Martins FF, Almeida CV, Moura CD. Efeito da inclusão de bagaço de girassol na ração sobre o desempenho e rendimento de carcaça de frangos de corte. Revista Portuguesa de Zootecnia 2003; 10(2):107-116.

Oliveira JP, Araújo LF, Junqueira OM. Farelo de girassol com suplementação enzimática para frangos de corte. Anais da Conferência APINCO de Ciência e Tecnologia; 2007; Santos, São Paulo. Brasil. p. 45.

Pinheiro JW, Fonseca NAN, Silva CA, Cabrera L, Bruneli FAT, Takahashi SE. Farelo de girassol na alimentação de frangos de corte em diferentes fases de desenvolvimento. Revista Brasileira de Zootecnia 2002; 31Suppl 3:1418-1425.

Rostagno HS, Albino LFT, Donzele JL, Gomes PC, Oliveira RF, Lopes DC, Ferreira AS, Barreto SLT. Tabelas brasileiras para aves e suínos: composição de alimentos e exigências nutricionais. 2. ed. Viçosa: UFV; 2005.

Senkoylu N, Dale N. Sunflower meal in poultry diets. World Poultry Science Journal 1999; 55(6):153-174.
Silva DJ, Queiroz C. Análise de alimentos (métodos químicos e biológicos). 3. ed. Viçosa: UFV; 2002.

Torin HR. Utilização do farelo de arroz industrial: composição e valor nutrificante em dietas recuperativas [dissertação]. Campinas (SP): Universidade Estadual de Campinas; 1991.

Universidade Federal de Viçosa. Sistema de análises estatísticas e genéticas - SAEG. Versão 8.0. Viçosa; 2000.

Valdivie M, Sardinas O, Garcia JA. The utilization of $20 \%$ sunflower seed meal in broiler diets. Cuban Journal of Agricultural Science 1982; 16(2):167-171.

Waldroup PW, Hillard CM, Mitchell RJ. Sunflower meal as a protein supplement for broiler diets. Feedstuffs 1970; 42(43):41.

Zatari IM, Sell JL. Effects of pelleting diets containing sunflower meal on the performance of broiler chickens. Animal Feed Science and Technology 1990; 30:121-129. 